\title{
Insulin-Like Growth Factor-Binding Protein 3
}

National Cancer Institute

\section{Source}

National Cancer Institute. Insulin-Like Growth Factor-Binding Protein 3. NCI Thesaurus.

Code C17509.

Insulin-like growth factor-binding protein 3 (291 aa, 32 kDa) is encoded by the human IGFBP3 gene. This protein plays a role in insulin-like growth factor signaling, apoptosis promotion, and cell proliferation inhibition. 